\title{
CZY JEZYK POLSKI JEST JEZZYKIEM ŻYDOWSKIM? O LINGWISTYCZNYCH DYLEMATACH POETÓW POLSKO-ŻYDOWSKICH DWUDZIESTOLECIA MIĘDZYWOJENNEGO
}

\author{
Slawomir Jacek ŻUREK (Katolicki Uniwersytet Lubelski Jana Pawła II)
}

\section{Dylematy językowe i tożsamościowe}

W latach 20. i 30. XX w. w prasie polsko-żydowskiej odnaleźć można wiele utworów poetyckich, będących świadectwem dylematów lingwistycznych ich autorów, które objawiają się ze szczególną intensywnością w kontekście ich narodowej i kulturowej tożsamości. Nie sposób w jednym artykule przywołać wszystkie te głosy ${ }^{1}$. Faktem jest, że żydowskość jako doświadczenie egzystencjalne wyrażana była w literaturze w czasach Drugiej Rzeczpospolitej w kilku porządkach semiotycznych². Tak tę kwestię postrzegał prawie dwadzieścia pięć lat temu pionier współczesnych badań nad polskożydowskim życiem literackim - Władysław Panas:

[...] w dwudziestoleciu międzywojennym żydowski paradygmat kulturowy i komunikacyjny realizował się w trzech językach i w trzech obiegach, [...] istniał między nimi przepływ ludzi i tekstów, [...] wielojęzyczność (ściślej: trójjęzyczność) była cechą nad-

${ }^{1}$ Znaczącą część tekstów poetyckich odnoszących się do tego zagadnienia można odnaleźć w zbiorze Międzywojenna poezja polsko-żydowska. Antologia (wybrała, opracowała, objaśnieniami i wstępem opatrzyła E. Prokop-Janiec, Kraków 1996).

${ }^{2} \mathrm{O}$ zjawisku tym szeroko pisała Monika Adamczyk-Garbowska w tomie Odcienie tożsamości. Literatura żydowska jako zjawisko wielojęzyczne (Lublin 2004). 
rzędną, [...] istniała wówczas wysoka podaż tłumaczeń (w takiej sytuacji komunikacyjnej translatorstwo nabiera zresztą szczególnego znaczenia, zmieniającego istotnie problematykę zazwyczaj uświadamianą w związku z przekładem) $)^{3}$.

Natomiast Chaim Löw — przedwojenny polsko-żydowski krytyk literacki i bystry obserwator współczesnej mu rzeczywistości kulturowej — jeszcze wcześniej niż Panas, bo osiemdziesiąt lat temu, tę prawidłowość, niejako od wewnątrz procesu trwania samego zjawiska, thumaczył tak:

Historia nasza wykazuje kilka takich okresów, w których tworzyliśmy wieczne wartości żydowskie nie w języku Biblii. Skoro możliwa była literatura żydowska w języku aramejskim, arabskim, greckim, łacińskim, hiszpańskim i niemieckim, to dlaczego nie w polskim ${ }^{4}$.

Najciekawsze jest jednak to, że wielu polskich Żydów zastanawia się nad tą problematyką, wyrażając swoje poglądy w tzw. języku krajowym ${ }^{5}$, czyli polszczyźnie. Język polski w latach 1918-1939 wśród Żydów, zamieszkujących Drugą Rzeczpospolitą, osiągnął status szczególny. Jak pisała Eugenia Prokop-Janiec, „w międzywojennych polsko-żydowskich kręgach literackich uznawano polszczyznę za język żydowskiej kultury”, a traktowano jak „most” między Żydami a Polakami, mający stać się w przyszłości fundamentem innego spoidła ich łączącego — „mostu kultury i podstawą nowej więzi społecznej"6. Bardzo ważnym elementem tworzenia się w XX w. nowoczesnej tożsamości u polskich Żydów była konieczność postrzegania żydowskiej kultury na zasadzie partnerstwa z innymi tradycjami europejskimi, jako systemy równorzędne. Stąd mówienie o sprawach żydowskich w różnych językach nieżydowskich traktowano w kręgach zasymilowanych modernistów z jednej strony jako sposób na pokazanie walorów własnych (czyli żydowskich), a z drugiej jako element integrujący obie społeczności. Trzeba jednak zaznaczyć, że wielu z polsko-żydowskich autorów, żyjących w Polsce w okresie międzywojennym, było aktywnych w języku jidysz (który do końca lat 30. XX w. pozostawał językiem mas żydowskich), a nawet nowohebrajskim (już w latach 20. XX w. mocno promowanym przez środowiska syjonistyczne). Tak więc w tamtym czasie swoją kulturową tożsamość Żydzi polscy wyrażali we wszystkich wymienionych powyżej językach ${ }^{7}$.

\section{Mowa żydowska, polska i hebrajska}

Przyglądając się dylematom lingwistycznym żydowskich pisarzy, tworzących w języku polskim, warto pochylić się nad trzema tekstami z tej licznej grupy poetyckich zapisów, nie lekceważąc pozostałych, lecz czyniąc z nich ważny kontekst interpre-

\footnotetext{
${ }^{3}$ W. Panas, ,Ja - polski poeta, hebrajski niemowa”. Literatura polsko-żydowska i żydowsko-polska (1918-1939), [w:] tegoż, Pismo i rana. Szkice o problematyce żydowskiej w literaturze polskiej, Lublin 1996, s. 43-44. 1934.

${ }^{4}$ Ch. Löw, Smok w stowiczem gnieździe (Żydzi w poezji odrodzonej Polski), Warszawa

${ }^{5}$ Kategorii tej użyła za Celią Stopnicką-Heller (taż, On the Edge of Destruction. Jews of Poland Between the Two Wars, New York 1980) Eugenia Prokop-Janiec w swej monografii o literaturze polsko-żydowskiej okresu 1918-1939: Międzywojenna literatura polsko-żydowska jako zjawisko kulturowe i artystyczne, Kraków 1992, s. 83.

${ }^{6}$ Tamże, s. 78.

7 Zob.: Ch. Shmeruk, Hebrajska, jidysz, polska. Trójjęzyczna kultura żydowska, tłum. M. Adamczyk-Grabowska, Cwiszyn 2011 nr 1-2, s. 22-23.
} 
tacyjny. Pierwszą cechą łączącą te utwory jest ich język - bo choć traktują o trzech różnych porządkach znakowych: polskim, hebrajskim i jidysz, to wszystkie zapisane zostały w polszczyźnie. Cechą drugą jest ich metajęzykowa tematyka — są to refleksje nad samym systemem kulturowo-semiotycznym, służącym poecie do artystycznego wyrażania. Cecha trzecia to ich aktualny i momentalny charakter (wszystkie ukazały się polsko-żydowskich dziennikach) — w roku 1933 w „Naszym Przeglądzie” (nr 99) został ogłoszony liryk Do mowy żydowskiej Eleazara Merchentrauma, a dwa lata później, w roku 1935 w „Opinii” — Do polskiej mowy (nr 11) i Do mowy hebrajskiej (nr 13) Daniela Ihra.

Marchentraum w swoim liryku od początku zaznacza, z jakiej pozycji będzie mówił o języku żydowskim (jidysz). Jest to optyka zasymilowanego Żyda, podległego od kilku pokoleń procesom akulturacyjnym. Już przodkowie osoby mówiącej (żyjący w Estonii) nie posługiwali się jidysz, nie czynili tego także jej rodzice — ani ojciec, ani matka. Język ten nie był również żadną alternatywą lingwistyczną dla syna, „co się urodził na mazowieckiej ziemi”. Poeta pisze po polsku i w tym języku zwraca się do swojego czytelnika, opowiadając o swej złożonej ostatecznie, na zawsze już utraconej relacji do mowy żydowskiej — ,Jak gorzko mi niewymownie, jak boli do żywego,/ Że nawet tych słów najprostszych inaczej wyznać nie umiem/ Jak w mowie Mickiewicza, Puszkina lub Heinego...”. Jego polszczyzna, niejako narzucona, jest spadkiem po poprzednich pokoleniach, stosunek do jidysz opisuje dramatycznym zwrotem: „O, mowo moja nieznana, tragicznie zaprzepaszczona" (Do mowy żydowskiej).

Zbliżoną, charakterystyczną dla najmłodszego pokolenia zasymilowanych Żydów, żyjących przed wojną w Polsce, relację do języków wykazuje inny poeta polskożydowski - Włodzimierz Słobodnik. Jednak ten artysta nie żałuje odejścia od języków żydowskich — jidysz i hebrajskiego. Dla niego polski jest własną, wybraną świadomie mową i strategią uzewnętrzniania żydowskiej tożsamości. Przypadek ten to, jak nazwał Panas, forma ,artykulacji Innego jako Takiego Samego" ${ }^{\text {: }}$

Inność lokuje on [Słobodnik] w sferze pochodzenia, przeszłości, wspomnień. Cały [jego] wysiłek poetycki [...] skierowany jest na zbliżenie do Polski i do polszczyzny. [...] Słobodnik [...] przywołuje archetypowy obraz polskiego poety — „lirnika mazowieckiego”. Inny jako „mazowiecki lirnik”, poeta Mazowsza — serca ziemi polskiej ${ }^{9}$.

Z zupełnie innej pozycji mówi o swoich wyborach językowych Daniel Ihr. Choć w wierszu Do polskiej mowy nazywa umieszczoną w tytule polszczyznę mową własną, uwitą z polskiego krajobrazu — „z polnych kwiatów / niezapominajek i bławatów”, mową „wiślaną i lipową”, rozbrzmiewającą „wśród krzywych wierzb”, to jednocześnie (i mocno to podkreśla) dystansuje się wobec niej, używając czasu przeszłego — „długoś mi była [S.J.Ż] mową moją”. Jednocześnie zdaje sobie sprawę z tego, że język polski przez lata wyznaczał jego granice poznawcze, a szczególnie ramy procesu adolescencji: „Słyszałem nad kołyską ciebie / Z ust matki w jasne, ciche rano”. Polszczyzna to zatem język matczyny, w którym czuł się jak „swój i brat”. Z mozołem budowany sielankowy obraz dopełnia w wierszu motyw słowiczego brzmienia języka polskiego, niegdyś oddającego najpełniej jego młodzieńcze przeżycia emocjonalne - używał go, będąc „w pierwszym niebie”, na ,pierwszym spotkaniu z ukochaną”. Z „mową słowiczą" (motyw mocno eksploatowany jako symbol polskości, również przez kryty-

\footnotetext{
${ }^{8}$ W. Panas, Pismo i rana. O literaturze polsko-żydowskiej, [w:] tegoż, Pismo i rana, s. 67.

${ }^{9}$ Tamże.
} 
ków literatury polsko-żydowskiej ${ }^{10}$ ), Ihr łączy skowrończość i smętność. Wszystko to nadaje doświadczeniom opisanym $\mathrm{w}$ wierszu charakter melancholijny. Także w ujęciu Merchentrauma mową młodzieńczej miłości jest polszczyzna (Do mowy żydowskiej). Mimo deklaratywnego sentymentu do mowy — ani hebrajski, ani jidysz nie kojarzą się z głosem kochanka. Poeta, odnosząc się do tytułowej mowy, dopowiada:

Niczyim ustom kochanym nie byłaś ożywczą rosą,

Nie kwitłaś mi, nie pachniałaś niczyim drogim imieniem.

Ihr w wierszu Do mowy hebrajskiej patrzy na polszczyznę z perspektywy umiłowania hebrajszczyzny. Jest to kulturowe spojrzenie syjonisty. W tej optyce kategorie stricte językowe stopniowo się rozszerzają - mowa tu już nie tylko o języku polskim jako takim, lecz w lingwistycznym kontekście o ,wietrznych nocach słowiańskich”, czego konsekwencją staje się wprowadzenie do uniwersum kulturowego kategorii religijnych. Osoba mówiąca w tym tekście, gdy przedstawia swoje doświadczenia nieżydowskie, przywołuje „Swantewidów (Światowidów) nad szklistą strugą” i „ognie świętojańskie", przyporządkowując polskość do kategorii z porządku religii naturalnych, pogańskich, a cały czas pozostawania w tym kręgu kulturowym określa mianem „błąkania”. Jedynym określeniem chrześcijańskim w wierszu jest wiatyk, czyli tzw. pokarm na wieczną drogę (łac. via — 'droga' i vaticum - 'zapas na drogę'), a więc komunia święta podawana choremu przed śmiercią. U Ihra wiatykiem przygotowanym na ziemiach słowiańskich nie był jednak chleb, o który przyszło mu wielokrotnie „kołatać na próżno”, lecz „obelga krwawa” i „klątwa w noc podróżną”. Doświadczenie polskości i polszczyzny kończy się dla mówiącego odrzuceniem i wygnaniem, a towarzyszy mu głos matki-hebrajszczyzny „wołający z dalekiej strony” (Do mowy hebrajskiej). Odrzucenie kreślone w wierszu Do polskiej mowy jest o wiele bardziej przykrym zjawiskiem:

$$
\begin{aligned}
& \text { Aż spragnionego napojono } \\
& \text { Żmijowym jadem i cykutą } \\
& \text { I proste słowo - wykrzywiono } \\
& \text { I proste wierne serce - struto. } \\
& \text { Słowo dzwoniące nad kołyską } \\
& \text { Przekreślił - ból, gorycz i gniew. } \\
& \text { Skończyło się na zawsze wszystko, } \\
& \text { Gdy się zaczęła - krew. }
\end{aligned}
$$

W tym wypadku w sytuacji wykluczenia, wydziedziczenia i prześladowania jedynym wyjściem jest emigracja z ,ziemi skutej mroźnym grudniem”, od której „odbiegły myśli i modlitwy”, które teraz „lecą z ptakami na południe”. Poeta gorzko konkluduje — „Ptaki powrócą — miłość nigdy” (Do polskiej mowy). Dopełnienie tego zwrotu geograficznego (z Polski krainy północnej do Palestyny leżącej na południu) opisane jest explicite w elegii do hebrajszczyzny. W Palestynie - i to ze źródła religijnego, którym jest grób Pramatki Racheli - „biali anieli” przynoszą mowę hebrajską, określaną mianem „szeptu jedynego". To tu „modlą się cedry dumne wszystkie”, to tu rozwija się ,wielka modlitwa w słowie”, u podstaw której leży „maleńkie słowo” „swoje, bliskie”, przed którym cała rzeczywistość skłania głowę — a którym jest pozostawiony w domyśle Tetragram (Do mowy hebrajskiej). W ten kulturowy porządek modlitewny włączona jest u Ihra cała przyroda:

${ }^{10}$ Zob. tytuł przywołanej powyżej rozprawy krytycznoliterackiej Chaima Löwa - Smok w stowiczem gnieździe (Żydzi w poezji odrodzonej Polski). 


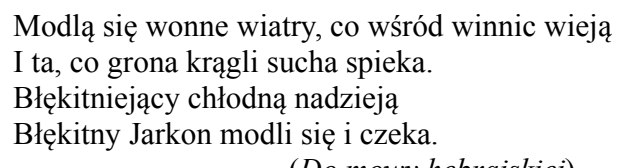

(Do mowy hebrajskiej)

Co jednak najbardziej zaskakujące, w tym palestyńskim krajobrazie pojawiają się znowu słowiki - które przypominają „dźwięczne dzwonki wielbłądzie”. W wierszu Do polskiej mowy były one wyznacznikami polszczyzny, tu, w liryku Do mowy hebrajskiej — „kląskają kananejskiej nocy”. Notabene zarysowana powyżej sytuacja liryczna bardzo przypomina wiersz innego przedwojennego polsko-żydowskiego poety, pozostającego także na krawędzi - między polszczyzną a hebrajszczyzną, i funkcjonującego w obu obiegach językowych: Elegję Romana Brandstaettera. W liryku tym, „w tej polskiej mojej mowie drży smutek żydowski, / A w polskich lipach płonie woń cedrów hebrajskich”. W innych miejscach artysta ten hebrajszczyznę nazywa „srebrną mową" (Pożegnanie muzy czarnoleskiej), „srebrną pieśnią” (Dzieje mojego rodu; oba wiersze z tomu Królestwo Trzeciej Światyni). Maurycy Szymel określa ją natomiast mianem „wolnej mowy” (Poetom ziemi walczacej, z tomu Powrót do domu, 1931).

Wracając do przywołanego wcześniej fragmentu wiersza Ihra Do mowy hebrajskiej, trzeba zaznaczyć, że mamy tu dopełnienie w postaci apostrofy: „- Błogosławionyś אבה ! Jahwe! Doszedł - który błądzil”, będącej trawestacją hebrajskiego powitania [baruch ha-ba - 'błogosławiony, który przybywa']. W ostatniej części utworu pojawia się antyjudaistyczny topos ahaswera - Żyda wiecznego tułacza, które w wierszu tym, jednak nie ma takiej wymowy. Poeta pisze: „Idę syn bezdomny”, „pies bezpański”, przez ,ziemi i nieba ogromy”. To, co go niejako niewoli, przywiązuje do polskości, to głos matki określany jako ,jęk słowiański” („A ty mnie matko wołasz — słyszę, słyszę -”). Sytuacja ta ostatecznie pozwala na określenie osoby mówiącej — to „niemy i niewidomy” poeta, który błąka się, skazany na nocną tułaczkę, czasie „północnej złej godziny”. Pragnie on powrócić w objęcia matczyne, mówi: „wyciągam ręce do twych dłoni”. Kim jest ta matka? Czy to ta mówiąca po polsku rodzicielka? A może w przenośnej odsłonie ujęta polszczyzna? Nieoczekiwana odpowiedź znajduje się w ostatniej strofie liryku:

Omackiem idę przez milczenie i mrok,

Wiem, że do serca przytulisz złego syna,

Że ustom - słowa, ślepym oczom wzrok

Dasz hebrajska mowo - matko jedyna.

Taki sam tragiczny motyw relacji między polszczyzną a hebrajskim niezwykle mocno wybrzmiewa w poezji Maurycego Schlangera, który mówi o skomplikowanej sytuacji artysty polsko-żydowskiego i swojej własnej: ,ja - polski poeta, hebrajski niemowa" (Wyznanie moje z tomu Idę, Kraków 1936). Postulatywny powrót do hebrajszczyzny obecny jest też u Brandstaettera, w Psalmie sentymentalnym („Opinia” 1935, nr 2): „Panie! Uczyń cud, aby po mojej śmierci / Płakała nad moim prochem, / Posypana żałobnym prochem / Hebrajska mowa”.

W podobnych kategoriach - nieistniejącego w rzeczywistości osoby mówiącej obiektu miłości, ujmuje mowę żydowską Eleazar Merchentraum: „Nikt mnie nie uczył Cię kochać”, „Obcy mi był rytm twych pieśni, nieznane słów twych znaczenie”. Przywołuje on też negatywne opinie o tym języku, będącego obiektem propagandowego ataku asymilatorów, z kręgu którego sam się wywodzi: ,[...] Słyszałam, że jesteś mową / Fanatyków i potępieńców, że jesteś marnym szwargotem". Mimo to w jego sercu 
„wzbierało, coś poza rozumem i głową, / Coś, co strzeliło nagle ogromną, żarliwą tęsknotą”. Osoba mówiąca, „długą drogą zmęczona”, wyznaje „Zbliżam się oto do ciebie po wyboistym ugorze". Pozostaje ona, podobnie jak ślepy i głuchy wędrowiec Ihra, w sytuacji tragicznej, mowa żydowska, jest „nieznana, tragicznie zaprzepaszczona”, „brzmiąca [...] z mów cudzoziemskich najbardziej obco może”. Tak jak język żydowski dla Merchentrauma i hebrajski dla Ihra, tak dla Szymla hebrajszczyzna pozostaje jedynie ważnym kontekstem kulturowym $\mathrm{w}$ jego poetyckich zmaganiach dokonywanych w polszczyźnie:

O, dobrzy, cisi pasterze, o biali ludzie biblijni,

Wy utajeni w gałęziach szerokich hebrajskich liter,

Pozwólcie iść w waszym cieniu mnie walczącemu bezsilnie

$\mathrm{Z}$ urokiem piastowych słów, piastowych nocy i świtów

(Elegia o mowie hebrajskiej, z tomu Powrót

do domu, 1931)

$* * *$

Zarówno Żyd-asymilator z wiersza Merchentrauma, jak i Żyd-syjonista z elegii lingwistycznych Ihra, zwracający się do trzech mów - żydowskiej, polskiej i hebrajskiej, pozostają mimo wszystko w polszczyźnie. Jest to dla nich sytuacja dokuczliwa, jak pisze Marchentraum — „gorzka”, która „boli do żywego”. Polsko-żydowscy poeci w latach trzydziestych odkrywali prawdę, że są skazani na różnicę ${ }^{11}$, czyli na mówienie w polszczyźnie o swoich żydowskich dylematach językowych, etycznych, religijnych i kulturowych ${ }^{12}$. Jak trafnie pisał Panas:

Tym, co wyróżnia zasadniczo całe żydowskie piśmiennictwo polskojęzyczne, co modeluje od wewnątrz, od samych podstaw ten dyskurs, jego stylistykę i semantykę, poetykę i etykę, tym, co jest ukryte, i tym, co jest jawne, w strukturze głębokiej i powierzchniowej, tym, co stanowi prawdę tego dyskursu - jest różnica. Różnica fundamentalna, źródłowa, archetypowa: między „swoim” i „obcym”, „takim samym” i „,innym”, „tożsamym” i „nietożsamym”. Tu wcielona w to, co najogólniej można określić jako „żydowskie" i to, co ,polskie”, skonkretyzowana w formie różnicy między żydowskim sensem i polskim językiem. W piśmiennictwie, które jest formowane w polszczyźnie,

11 „Utwory literackie, o których tu mowa, są wypowiedzeniem różnicy, wysłowieniem jej sensu. W tekstach artystycznych, nawet tych słabszych, mowa ma charakter kreatywny i nie da się sprowadzić do roli narzędzia. Tym samym napięcie między sensem a znakiem językowym jawi się jako stan naturalny. W tę różnicę między biegunem żydowskich treści i mową polską wchodzi coś trzeciego: literatura. W ówczesnym pisarstwie Brandstaettera, w poezji Szymla i Eker, w krytyce Löwa, w pamfletach Imbera, w eseistyce Steina trwa dyskurs różnicy, znajdującej rozmaity wyraz stylistyczny i różnie tematyzowanej. Lecz zawsze źródłowej i produktywnej. Bywa nazywana różnicą językową między mową polską a mową hebrajską (elegie o mowie hebrajskiej Brandstaettera i Szymla), asymetrią (,polski poeta, hebrajski niemowa” — „w nie mojej mowie zgubnie zakochany": M. Schlanger, M. Szymel). Ale bywa i nienazwana, niezidentyfikowana tematycznie, bywa samą zasadą wymuszającą wypowiedź. Przenosi się wtedy gdzieś na poziom egzystencjalny, trudno uchwytny przez krytykę literacką”; W. Panas, „Ja - polski poeta, hebrajski niemowa", s. 49.

${ }^{12}$ Po wprowadzeniu w latach 30. obowiązku szkolnego także dla obywateli polskich wyznania mojżeszowego bardzo dynamicznie zaczęła wzrastać znajomość języka polskiego szczególnie wśród dzieci i młodzieży żydowskiej. Wielu jej przedstawicieli zaczęło także pisać i publikować w języku polskim. „Polonizacja tak szybko posuwała się naprzód, że debiutowali czasem tomikami poezji niewładający dobrze językiem polskim"; Ch. Löw, Smok w słowiczem gnieździe, przypis nr 4, s. 4. 
różnica ta stanowi podstawę ontologiczną, określa sposób istnienia. Ta źródłowa sytuacja powoduje, że jest to dyskurs — potencjalnie — dwubiegunowy, mający dwa możliwe centra znaczeniowe, wewnętrznie dwoisty. I jest to przestrzeń dramatyczna ${ }^{13}$.

$\mathrm{W}$ ten sposób polszczyzna w połowie lat trzydziestych XX w. dla większości polsko-żydowskich autorów stała się jednym z języków żydowskich — w porządku komunikacyjnym na krótko, bo tylko na kilka lat, lecz w porządku kulturowym - na zawsze.

\footnotetext{
${ }^{13}$ W. Panas, ,Ja - polski poeta, hebrajski niemowa”, s. 48.
} 


\section{Aneks}

Ani nie byłaś mową pradziadów moich z Estonii,

Ani cię nie znał mój ojciec — charlottenburski chemik

I już nie pozna, ani cię nie obroni

Syn mój, co się urodził na mazowieckiej ziemi.

Nie byłaś mową mej matki, ani kochanka głosem,

Obcy mi był rytm twych pieśni, nieznane słów twych znaczenie,

Niczyim ustom kochanym nie byłaś ożywczą rosą,

Nie kwitłaś mi, nie pachniałaś niczyim drogim imieniem.

Nikt mnie nie uczył Cię kochać. Słyszałam, że jesteś mową Fanatyków i potępieńców, że jesteś marnym szwargotem, Ale coś w sercu wzbierało, coś poza rozumem i głową, Coś, co strzeliło nagle ogromną, żarliwą tęsknotą.

Po stokroć smutne dzieciństwo! Dziś długa drogą zmęczona Zbliżam się oto do ciebie po wyboistym ugorze.

O, mowo moja nieznana, tragicznie zaprzepaszczona,

Brzmiąca mi z mów cudzoziemskich najbardziej obco może.

I nikt, nikt nie pojmie tego, nikt nie zrozumie,

Jak gorzko mi niewymownie, jak boli do żywego,

Że nawet tych słów najprostszych inaczej wyznać nie umiem Jak w mowie Mickiewicza, Puszkina lub Heinego...

(Eleazar Merchentraum, Do mowy żydowskiej, „Nasz Przegląd” 1933, nr 99) 
Długoś mi była moją mową -

Mowo uwita z polnych kwiatów,

Niezapominajek i bławatów,

Mowo wiślana i lipowa.

U twoich nóg, pod strzechy twemi

Długom żył jako swój i brat.

Na czarnej twojej żyznej ziemi

Wśród krzywych wierzb - był prosty świat.

Słyszałem nad kołyską ciebie

$\mathrm{Z}$ ust matki w jasne, ciche rano.

Brzmiałaś słowiczo w pierwszym niebie -

$\mathrm{W}$ pierwszym spotkaniu $\mathrm{z}$ ukochaną.

Twym słowem smętnym i skowrończym

Pierwsze się tłumaczyły łzy,

W samotnym zmierzchu, gdzie się kończy

Miłość - czekałaś na mnie - ty.

Az spragnionego napojono

Żmijowym jadem i cykutą

I proste słowo - wykrzywiono

I proste wierne serce - struto.

Słowo dzwoniące nad kołyską

Przekreślił — ból, gorycz i gniew.

Skończyło się na zawsze wszystko,

Gdy się zaczęła - krew.

Od ziemi skutej mroźnym grudniem

Odbiegły myśli i modlitwy.

Lecą z ptakami na południe.

Ptaki powrócą — miłość nigdy.

(Daniel Ihr, Do polskiej mowy, „Opinia” 1935, nr 11) 
Trzeba mi było błąkać się długo

Wśród wietrznych nocy słowiańskich,

U Swantewidów nad szklistą strugą,

U ogni świętojańskich.

Trzeba mi było u progów stawać,

Do drzwi kołatać na próżno

I zamiast chleba — obelgę krwawą

I klątwę w noc podróżną

Brać na wiatyk, ażebym pojął

Bezsenny i znużony,

Twój głos — matko moja -

Wołający z dalekiej strony.

Przez jęk wichrowy, śmiech wierzycieli

I lęk północnej godziny -

$\mathrm{Z}$ grobu Racheli biali anieli

Przynieśli szept jedyny.

Maleńkie słowo, a swoje, bliskie,

Wielka modlitwa w słowie:

Modlą się cedry dumne wszystkie

Głowę skłaniając Jehowie.

Modlą się wonne wiatry, co wśród winnic wieją

I ta, co grona krągli sucha spieka.

Błękitniejący chłodną nadzieją

Błękitny Jarkon modli się i czeka.

Kląskają kananejskiej nocy

Słowiki — dźwięczne dzwonki wielbłądzie.

W bukłaku śpiewna woda bulgoce.

— Błogosławionyś Jahwe! Doszedł — który błądził.

A ty mnie matko wołasz — słyszę, słyszę —

Wskróś wichrów jęk słowiańskich,

Między domostw i serc zawartych ciszę

Idę syn bezdomny twój i — pies bezpański.

Przez lęk północnej złej godziny,

Ziemi i nieba ogromy,

Wyciągam ręce do twych dłoni matczynych -

Niemy i niewidomy.

Omackiem idę przez milczenie i mrok,

Wiem, że do serca przytulisz złego syna,

Że ustom - słowa, ślepym oczom wzrok

Dasz hebrajska mowo - matko jedyna.

(Daniel Ihr, Do mowy hebrajskiej, „Opinia” 1935, nr 13) 


\section{LITERATURA}

M. Adamczyk-Garbowska, Odcienie tożsamości. Literatura żydowska jako zjawisko wielojęzyczne, Lublin 2004;

D. Ihr, Do polskiej mowy, Opinia $1935 \mathrm{nr} 11$;

D. Ihr, Do mowy hebrajskiej, Opinia $1935 \mathrm{nr}$ 13;

Ch. Löw, Smok w słowiczem gnieździe (Żydzi w poezji odrodzonej Polski), Warszawa 1934;

Międzywojenna poezja polsko-żydowska. Antologia (wybrała, opracowała, objaśnieniami i wstępem opatrzyła E. Prokop-Janiec, Kraków 1996;

E. Merchentraum, Do mowy żydowskiej, Nasz Przegląd 1933 nr 99;

W. Panas, „Ja - polski poeta, hebrajski niemowa”. Literatura polsko-żydowska i żydowsko-polska 1918-1939, [w:] tegoż, Pismo i rana. Szkice o problematyce żydowskiej w literaturze polskiej, Lublin 1996, s. 41-55;

W. Panas, Pismo i rana. O literaturze polsko-żydowskiej, [w:] tegoż, Pismo i rana. Szkice o problematyce żydowskiej w literaturze polskiej, Lublin 1996, s. 57-74;

E. Prokop-Janiec, Międzywojenna literatura polsko-żydowska jako zjawisko kulturowe i artystyczne, Kraków 1992;

Ch. Shmeruk, Hebrajska, jidysz, polska. Trójjęzyczna kultura żydowska, thum. M. Adamczyk-Grabowska, Cwiszyn $2011 \mathrm{nr}$ 1/2, s. 22-33;

C. Stopnicka-Heller, On the Edge of Destruction. Jews of Poland Between the Two Wars, New York 1980.

\section{IS POLISH A JEWISH LANGUAGE? LINGUISTIC DILEMMAS OF POLISH-JEWISH POETS OF THE INTERBELLUM}

Evidence of their authors' linguistic dilemmas in the context of their national and cultural identity, can be found in many poems published by the Polish-Jewish press of the 1920s and 1930s. Jewishness understood as an existential experience was expressed in literature in the times of the Second Polish Republic in three semiotic orders-in Polish, Hebrew and Yiddish (this issue has been researched by W. Panas, Ch. Shmeruk, E. Prokop-Janiec, and M. AdamczykGarbowska). Three poems written in Polish are the object of the present analysis: "Do mowy żydowskiej" (To the Jewish Tongue) by Eleazar Merchentraum, "Do polskiej mowy" (To the Polish Tongue) and "Do mowy hebrajskiej" ("To the Hebrew Tongue") - both by Daniel Ihr. They contain reflections on cultural-semiotic systems used by the poets as an artistic means of expression of their identity. However, both the assimilationist Jew from Merchentraum's poem and the Zionist from Ihr's linguistic elegies are addressing the three languages-Jewish, Polish and Hebrew - using the Polish language. Polish-Jewish poets in the 1930s discovered the truth of being doomed to otherness, fated to talk about their Jewish dilemmas-linguistic, ethical, religious and cultural - in Polish. So by the middle of the 1930s, the Polish language had become one of the Jewish languages for most Polish-Jewish authors - in terms of communication, just for a few years; nevertheless, in terms of culture-forever.

KEY WORDS: Polish-Jewish literature of the 1918-1939 period; identity; Daniel Ihr; Eleazar Merchentraum. 